\title{
Evaluation of Platelet Rich Fibrin Sandwiching technique with mixture of alloplastic bone graft and Hyaluronic Acid in repair of Recurrent Oronasal Fistula
}

\author{
Abdel Aziz B. Abdullah *1 and Mohammed M. Al-Ashmawy*
}

Codex : 01/2021/04

Aadj@azhar.edu.eg

\section{KEYWORDS}

PRF, HyA, alveolar cleft, oronasal fistula,

alveolar bone grafting, CBCT

1. Department of Oral and Maxillofacial Surgery, Faculty of Dental Medicine, Assiut, Al-Azhar University, Egypt.

* Corresponding Author e-mail: Abdelazizbaiomy@azhar.edu.eg

\begin{abstract}
Aim: is to evaluate efficacy of platelet rich fibrin (PRF) sandwiching technique associated with hyaluronic acid (HyA) mixed with alloplastic bone graft in closure of recurrent oronasal fistula after previously alveolar cleft grafting. Subjects and Methods: Our study conducted on 24 patients with recurrent unilateral oronasal fistula complaining of oronasal leakage. They were divided into two random equal groups. Group I, alveolar cleft defect was packed with alloplastic bone graft ( osteon II collagen) between two layers of PRF gel. While, in group II, alveolar cleft defect was packed with a mixture of alloplastic bone graft (osteon II collagen) and HyA between the two layers of PRF gel. All patients were observed clinically and radiographically (CBCT) for evaluation after three and six months postoperatively. Results: Our clinical results revealed that, all patients had uneventful wound healing except 4 cases in group I and one case in group II which had wound dehiscence and graft exposure at 1-week postoperatively. The radiographic results by CBCT scans showed a better new bone formation and good osseous union obliterating the oronasal defect.in group II than group I. There was a significant difference between bone density and bone resorption values in both groups at all intervals. Conclusion : Our results demonstrated that PRF sandwiching technique combined with a mixture of alloplastic bone graft and HyA could provide a favorable bony and soft tissue barriers for closure of recurrent oronasal fistula in alveolar cleft patients.
\end{abstract}

\section{INTRODUCTION}

Repair of cleft alveolus with alveolar bone grafting (ABG) is an essential step in the overall management of a cleft lip and palate patients. Secondary ABG procedure between 9 and 12 years of age has been established as the "golden standard" for alveolar cleft reconstruction ${ }^{(1-3)}$. Because of the treatment at this time allows stabilization of the maxillary arch, closure of the oronasal fistula, normalization of growth at the cleft site, and creation of bony support for eruption of adjacent permanent teeth ${ }^{(4,5)}$. The occurrence of ABG failure leading to anterior palatal fistula following surgery clearly compromises these goals ${ }^{(6 \& 7)}$. 
The main cause of $A B G$ failure is the dehiscence leading to exposure, and contamination of bone graft $^{(1,3)}$. Early dehiscence and fistulae are primarily caused by errors in technique such as inadequate stabilization, closure under tension, injury at reintubation, poor handling of the tissue, failure to achieve a layered closure, and postoperative bleeding and infection ${ }^{(8,9)}$.

Several authors ${ }^{(1,4,10)}$ had concluded that adequate dissection, definition of anatomical planes, and precise suturing are paramount for a good result. However, this is often not enough. Sometimes, there is an anatomical limitation to make a suitable soft-tissue scaffold to be filled with bone graft. Accordingly, the lack of a proper closure of anatomical planes can lead to contamination of graft with partial or total loss of bone graft ${ }^{(10)}$.

There are several trials ${ }^{(5,11,12)}$ were performed to use Platelet-rich fibrin in alveolar cleft grafting, with striking its results in bone and tissue regeneration. In these trails, PRF had been used to be mixed with bone graft to improve osteogenic capacity of graft or as a membrane, functioning as a biological and physical barrier .

Actually, PRF membrane has regenerative proprieties such as induce endothelial cell proliferation and improved wound angiogenesis. Also, it has a high content of leukocytes which might have a role in regulation of inflammation and prevention of infection. All these properties help in acceleration of wound healing of soft tissue and prevent occurrence of wound dehiscence ${ }^{(13-16)}$.

For the same object, several researchers ${ }^{(17,18)}$ had reported that application of HyA gel may reduce bacterial contamination of surgical wound site, thereby, lessening risk of post-surgical infection and promoting more predictable bone generation. Where, it has osteoinductive, bacteriostatic, and anti- inflammatory properties.

Accordingly, the hypophysis of current study was HyA have adjunctive role with double layer of
PRF gel in acceleration of wound healing and bone regeneration and prevent recurrent anterior palatal fistula. Therefore,the present study was concerned to evaluate efficacy of PRF sandwiching technique with alloplastic bone graft alone or associated with HyA application in closure of recurrent oronasal fistula in alveolar cleft patients.

\section{PATIENTS AND METHODS}

This study was conducted on 24 non-syndromic patients (9 females, 15 males) complaining from recurrent unilateral congenital alveolar cleft and oronasal leakage, requiring treatment of their complaints. Patient ages were ranged from 9 to 16 years (average 12.5 years). These patients were obtained from the Out-patient Clinic of Oral and Maxillofacial Surgery Department, Faculty of Dentistry, Al-Azhar university-Assiut branch. Clinical study was extended for 4 years (from July 2016 till Jun 2020). Research methods were illustrated to all patients and they signed an informed consent form before the study. The study was conducted according to rules of ethics declared by Helsinki, and ethical committee approval was obtained from Al-Azhar ethical committee.

\section{Selection criteria:}

Selection of patients was based on following criteria: patients should have a unilateral cleft alveolus with considerable size, accompanied by cleft lip and palate that was pretreated, absence of any systemic disorders that may influence the course of wound healing, and failed previous grafting attempts at cleft site. Also, exclusion criteria included patients with syndromic diseases, any those who didn't need for maxillary expansion before surgery .

\section{Preoperative assessment}

Preoperative procedures included history taking, intraoral and extraoral clinical examination, patient photograph from various views, and study cast. After clinical examination, a complete radiological as- 
sessment including a cone beam computed tomography (CBCT) to estimate position of permanent lateral incisor, if present, or central incisor, or canine adjacent to cleft, as well as assessing size and shape of alveolar defect. Orthodontic palatal expansion was performed firstly for cases presented with collapsed arch before alveolar bone grafting.

\section{Patients grouping:}

In all patients bone graft was covered using PRF sandwiching technique (two layers of PRF membrane one at palatal side and second layer at labial aspect).

The patients were divided randomly into two equal groups using online software (https://www. randomizer.org) according to type of bone graft used as following :

- Group I: consist of 12 patients having recurrent alveolar cleft were grafted with osteon II collagen (GENOSS, Dentium. Co. Ltd, Suwon, South Korea) only.

- Group II : consist of 12 patients having recurrent alveolar cleft were grafted with osteon II collagen (GENOSS, Dentium. Co. Ltd, Suwon, South Korea) mixed with Hy A gel (Hyadent, BioScience GmbH -Germany).

\section{Preparation of platelet-rich fibrin : ${ }^{(14,19)}$}

Prior to the surgery, $20 \mathrm{ml}$ fresh venous blood was taken from each patient and transferred into sterile tubes. As a standard protocol, tubes were then quickly placed into table centrifuge (Eppendorf Centrifuge 5804, Germany) which was adjusted to $3,000 \mathrm{rpm}$ for $10 \mathrm{~min}$. The tubes were then removed from the centrifuge. Given the lack of anticoagulant in the tubes, there were three distinct layers inside each tube. These layers included platelet-poor plasma at the top most layer, PRF in the middle zone, and the red blood cells in the lowest layer. Middle yellowish gel layer representing Choukroun's PRF, target layer that can be removed by sterile tweezer.
PRF gel was collected from tubes and implanted directly into operated site as barriers.

\section{Operative procedure (Fig.1):}

Patients were prepared for surgery with basic traditional method. All operations were done under general anaesthesia with endotracheal intubation. Preparation of recipient sites was similar in all patients, whereas, labial mucoperiosteal flaps were reflected from bone and sutured to each other, then nasal mucosa was repaired to close oronasal fistula. The palatal mucoperiosteal flaps were reflected and sutured to each other to repair palatal mucosa of palatal side of the cleft . Bone grafting associated with PRF sandwich technique was applied as following :

- Group I, PRF gel is placed covering suture line of nasal and palatal mucosa. Then, osteon II collagen bone graft was packed into alveolar cleft site. Finally, another layer of PRF gel is inserted covering bone graft,underneath labial mucoperiosteal flaps.

- Group II, PRF gel is placed at palatal and labial aspects as the same manner in group I,except that osteon II collagen bone graft was mixed with HyA gel and was packed into the alveolar cleft site.

Finally, labial and palatal flaps were raised and mobilized to have a watertight tension free closure of mucosa by interrupted 3/0 vicryl sutures in both groups.

\section{Postoperative care and follow-up:-}

\section{Postoperative care:}

Patients were instructed to have adequate post-surgical medications and to avoid postoperative complications such as infection, and edema follow up patients were closely observed daily in first week and then asked to attend for follow-up at $2^{\text {nd }}, 3^{\text {rd }}$ and $4^{\text {th }}$ weeks. At the end of 3,6 months postoperatively for clinical and radiographic evaluation were performed. 


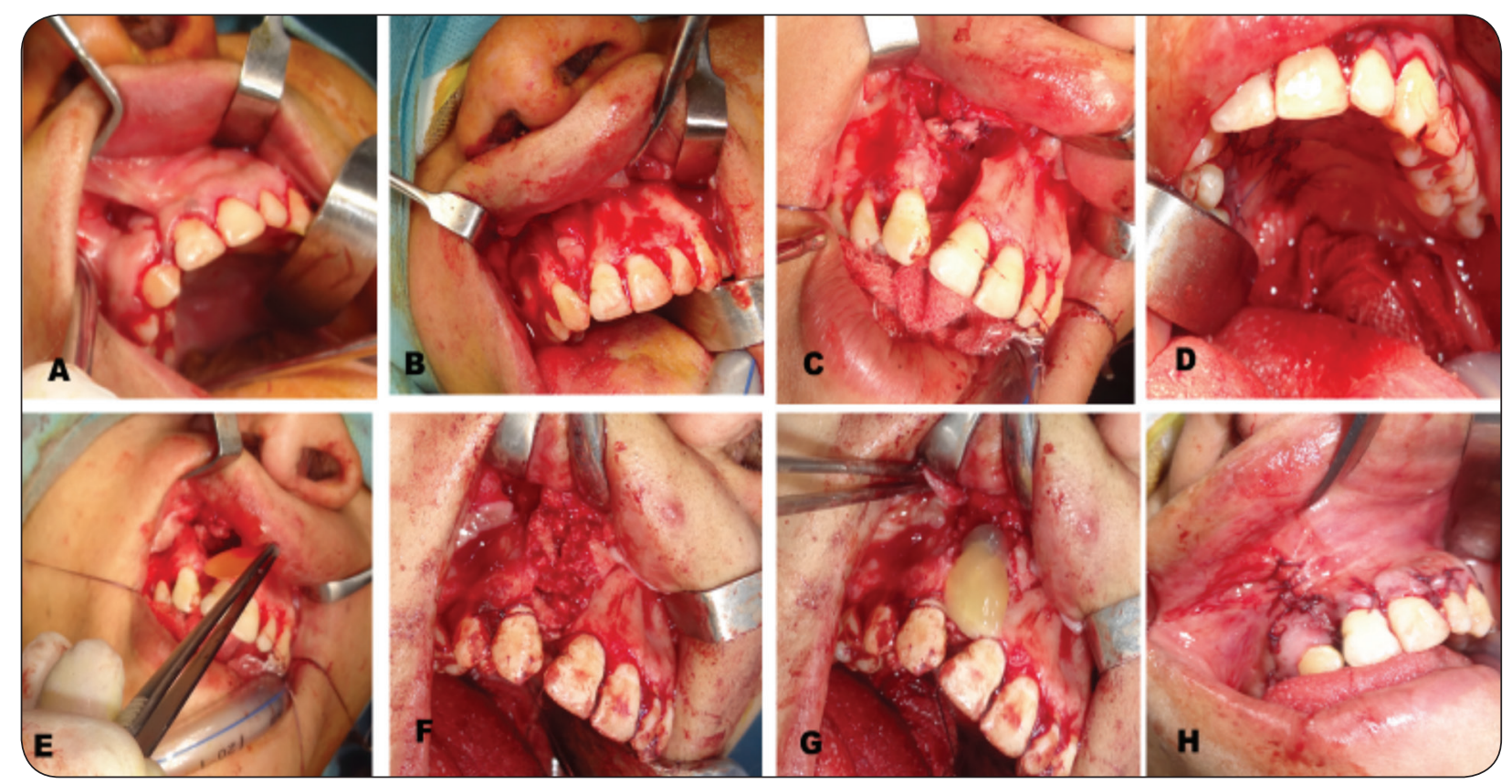

Fig. (1) Showing steps of surgical procedures in group II (A) Surgical incision (B) Reflection of labial mucoperiosteal flap (C) Closure of nasal mucosa (D) Closure of palatal flaps (E) Application of PRF gel at palatal side (F) Packing of mixture of osteon II collagen and HyA (G) Application of PRF gel at labial side (H) Closure of labial flaps

\section{Postoperative clinical evaluation:}

Clinical evaluation was involving observation of following clinical parameters:

- Wound examination for suture breakdown, dehiscence, swelling, infection, edema, hematoma, graft rejection and presence of oronasal fistula.

- Patient asked for pain or any nasal regurgitation.

\section{Postoperative radiographic assessment:}

Radiographic assessment postoperatively by cone beam CT (CBCT) images was done at 3,6 months. The CBCT images were obtained using Kodak 9500 unit (Kodak 9500 cone beam 3D system, Carestream Dental LLC 3625 Cumberland Blvd.St.700 Atlanta) with an amorphous silicon flat-panel image detector and its imaging software was CS 3D imaging v3.2.12. The imaging parameters were: 60 - $90 \mathrm{kV}$ (pulsed mode), 2 - $15 \mathrm{~mA}$, frequency of $140 \mathrm{kHz}$, effective scan time of $10.8 \mathrm{~s}$, focal spot of $0.7 \mathrm{~mm}$, and voxel size of $0.2 \mathrm{~mm}$. The field of view (FOV) program used was the medium field (half skull) program: $915 \mathrm{~cm}$.

Bone density was evaluated using Hansfield units (HU) in a qualitative analysis. In order to evaluate bone density of the graft, common graft areas in both images of each patient were diagnosed. As grafted bone was fully distinguished from adjacent bones, a circle was drawn by software in equal dimensions just in graft area for purpose of density measurement. As grafted bone was completely recognizable from surrounded bones, in each image, the height of graft and its thickness were measured in all CBCT cuts in millimetres, and their mean values were used for statistical analysis. Collection of all slices with bone block was stacked to produce a 3D structure and volume calculation was performed with same protocol described in previous studies ${ }^{(21,22)}$. The volume calculation for each case was repeated two times by the same observer and the mean data at different follow-up time points was presented with V3 (3-month postoperative) and V6 (6-month postoperative). Resorption rate was calculated as a percentage using this formula (V3 -V6)/ V3 $\times 100 \%{ }^{(21)}$ ( Fig.2). 


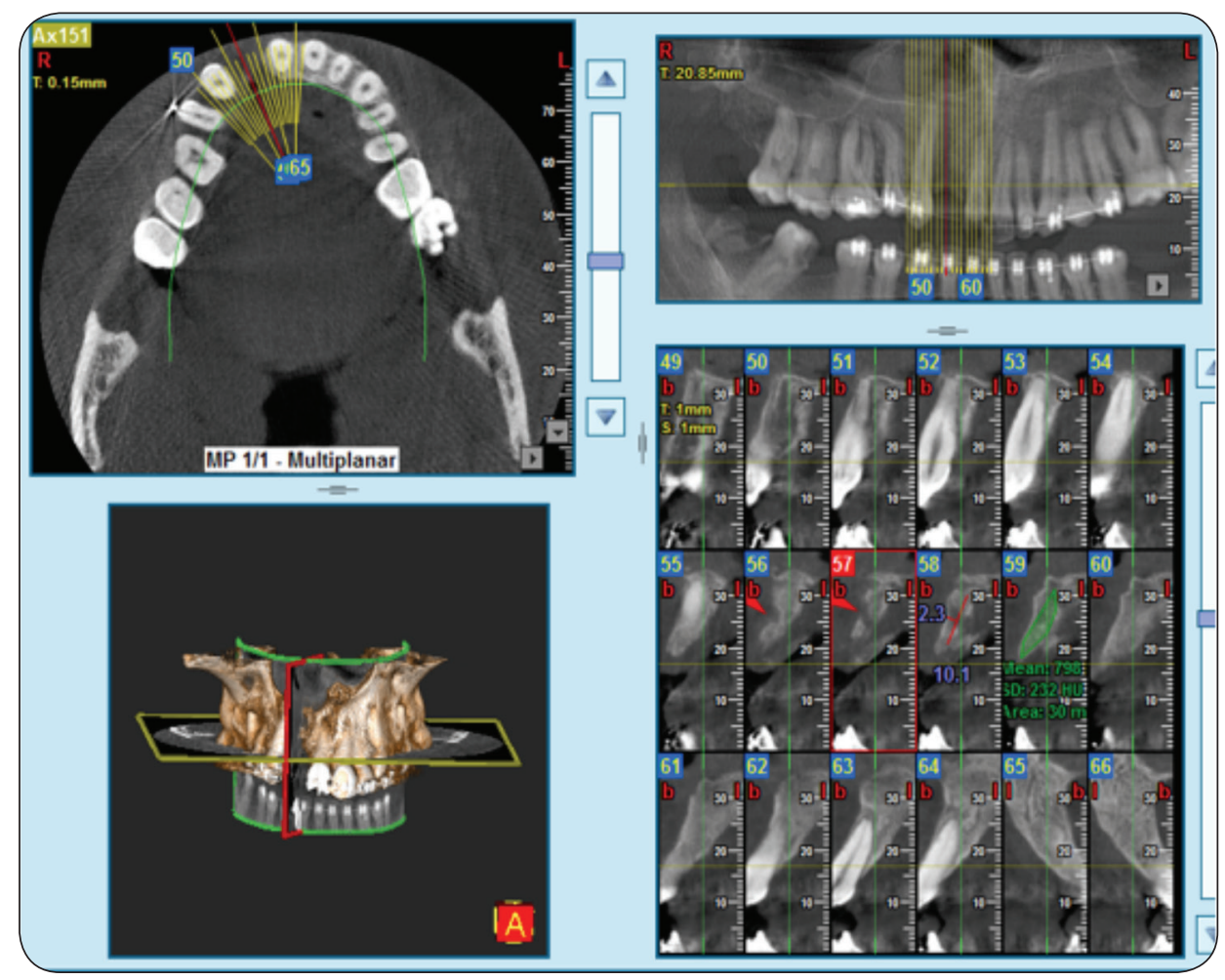

Fig. (2) Showing CBCT evaluation at 3 month in group II

\section{Statistical analysis}

Numerical data were presented as mean and standard deviation values. To compare 3 , and 6 month changes for both groups, paired t test was applied when there was normal distribution, and a Wilcoxon test was applied when there was a nonnormal distribution. To compare between groups, $\mathrm{t}$ test was applied when there was normal distribution, and Mann-Whitney test was applied when there was a non-normal distribution. The significance level was set at $\mathrm{P} \leq 0.05$. Statistical analysis was performed with SPSS 17.0@ ${ }^{\circledR}$ (Statistical Package for Scientific Studies) for Windows.

\section{RESULTS}

None of patients were excluded or eliminated because all continued their evaluations for at least 6 months. We performed 24 surgical closures of palatal fistulas in 24 patients ( $37.5 \%$ female $\& 62.5 \%$ males). All patients had previously undergone surgical closure of fistula, without success at 2 of 3 times. According to Cohen ${ }^{20}$ classification for size of fistulas, we had found 2 small (8.3\%), 8 medium
(33.3\%) and 14 large (58.3\%) fistulas. Fistulae were found in left side in $18(75 \%)$ of cases and in the right in 6 cases $(25 \%)$.

\section{Clinical results:}

Postoperative wound healing in both groups was uneventful except 4 cases of group I (33.3\%) and one case in group II (8.3\%) that showed dehiscence and stitch abscess at releasing incision of mucoperiosteal flap with bare area of bone lateral to the defect, which was treated with vigorous mouth wash application, in addition to that, patient instruction of good oral hygiene and periodontal pack application that was changed every week up to soft tissue healing by secondary intention.. No bleeding was observed in both groups and postoperative swelling subsided after 7 to 10 days in both groups. At 6 month interval, all patients had showed stabilization of the teeth adjacent to the cleft with stable arch contour. All oronasal fistulae were closed and showed good normal pink color of gingiva with better contour (Fig3A ) except one case in group I (8.3\%). 

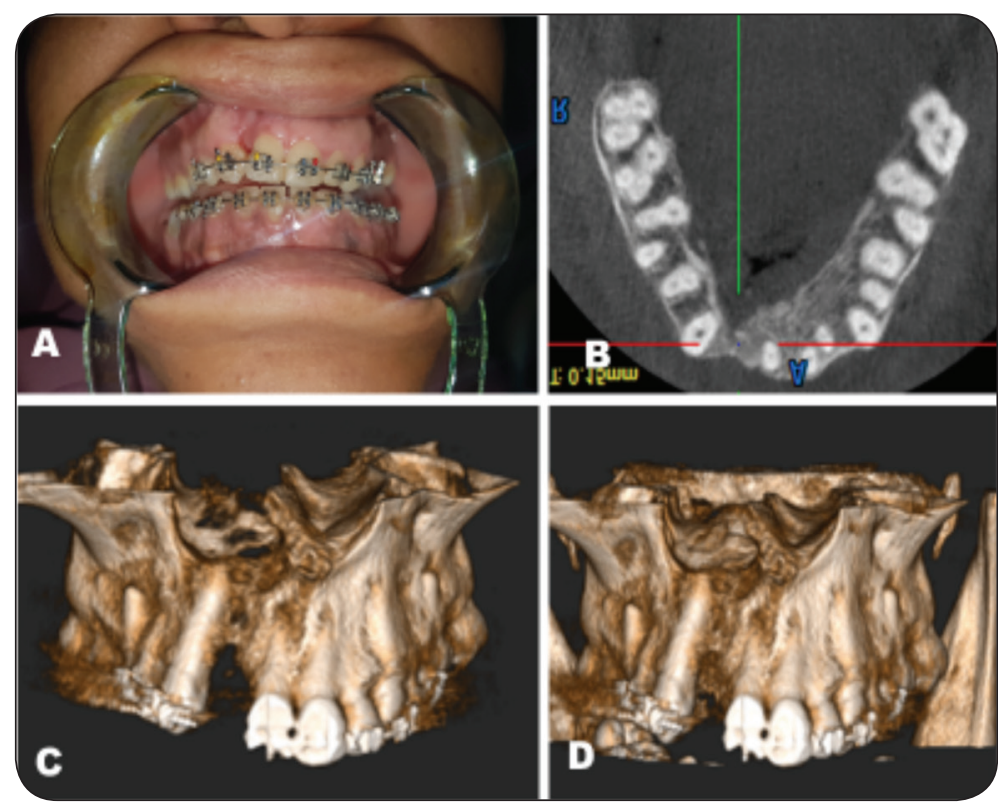

Fig. (3) (A) Clinical intraoral photograph showing complete closure of oronasal fistula in group II at 3 month (B) axial cut of CBCT showing complete bone bridge at alveolar cleft region at 6 month in group II ( C) 3D of $\mathrm{CBCT}$ of case in group II at 3 month (D) 3D of CBCT at 6 month

\section{Radiographic results:}

Results showed that changes of bone graft thickness were not statistically significant in both groups $(\mathrm{P}=0.78)$. There was no significant difference between groups in terms of the mean thickness difference of the graft at both 3 month $(\mathrm{P}=0.86)$ and 6 month $(\mathrm{P}=0.79)$. Regards to results of paired sample t-test, group II showed statistically non -significant changes in graft thickness at 6 month, compared to that at 3 month $(\mathrm{P}=0.79$; Table.1). Analysis of covariance showed that bone thickness reduction of graft packed in the cleft area in group I was $0.3 \mathrm{~mm}$ more than that in group II after 6 months, which was not statistically significant $(\mathrm{P}=0.78)$. Regarding bone graft height, there was no statistically significant difference between two groups at both 3 and 6 months $(\mathrm{P}>0.05)$. Therefore, the reduction changes at graft site from 3 to 6 moth were not statistically significant for both groups $(\mathrm{P}=0.92)$ ( table 1) (Fig3 B,C,D).

Bone density values showed statistically significant difference between both groups at 3 month interval and highly statistically significant difference at 6 month interval. In group I, mean bone densities of the graft were $404.1 \pm 170.9$ and $302.83 \pm 128.82 \mathrm{HUs}$ at 3 and 6 month, respectively. These mean values were obtained as $445.3 \pm 125.93$ and $392.8 \pm 163.8$ in group II, respectively. Regarding bone graft volume at postoperative intervals, there was statistically significant difference between two groups at both 3 month $(\mathrm{P} \leq 0.05)$ and highly statistically significant difference at 6 month $(\mathrm{P} \leq 0.001)$. Results presented that rate of bone graft resorption at 6 month interval was faster in group I ( 29.2\%) than group II (19.7\%) with highly statistically significant difference between both groups $(\mathrm{P} \leq 0.001)$ ( table 1$)$. 
Table 1: Comparison between means values and standard deviation of radiographic measurements in study groups at different intervals.

\begin{tabular}{|c|c|c|c|c|c|}
\hline & Intervals & $\begin{array}{c}\text { Group I } \\
\text { Mean } \pm \text { SD }\end{array}$ & $\begin{array}{c}\text { Group II } \\
\text { Mean } \pm \text { SD }\end{array}$ & $\mathrm{t}$ & $\mathrm{P}$ \\
\hline \multirow{4}{*}{$\begin{array}{l}\text { Graft thickness } \\
(\mathrm{mm})\end{array}$} & $3 \mathrm{~m}$ & $14.1 \pm 4.8$ & $14.1 \pm 4.9$ & 0.10 & 0.86 \\
\hline & $6 \mathrm{~m}$ & $11.5 \pm 4.6$ & $11.0 \pm 2.1$ & 0.35 & 0.79 \\
\hline & \multicolumn{5}{|c|}{ Paired sample t-test } \\
\hline & $3 \mathrm{~m}$ vs $6 \mathrm{~m}$ & $3.4 \pm 0.2$ & $3.1 \pm 2.8$ & 0.54 & 0.78 \\
\hline \multirow{4}{*}{$\begin{array}{l}\text { Graft height } \\
\quad(\mathrm{mm})\end{array}$} & $3 \mathrm{~m}$ & $13.8 \pm 4.0$ & $11.5 \pm 5.1$ & 1.12 & 0.42 \\
\hline & $6 \mathrm{~m}$ & $11.2 \pm 3.6$ & $10.7 \pm 3.6$ & 2.03 & 0.37 \\
\hline & \multicolumn{5}{|c|}{ Paired sample t-test } \\
\hline & $3 \mathrm{~m}$ vs $6 \mathrm{~m}$ & $2.2 \pm 1.6$ & $1.2 \pm 2.5$ & 0.37 & 0.92 \\
\hline \multirow{4}{*}{$\begin{array}{l}\text { Bone density } \\
\text { (HU) }\end{array}$} & $3 \mathrm{~m}$ & $404.1 \pm 170.9$ & $445.3 \pm 125.93$ & 3.6 & $0.02^{*}$ \\
\hline & $6 \mathrm{~m}$ & $302.83 \pm 128.82$ & $392.8 \pm 163.8$ & 3.2 & $0.01 * *$ \\
\hline & \multicolumn{5}{|c|}{ Paired sample t-test } \\
\hline & $3 \mathrm{~m}$ vs $6 \mathrm{~m}$ & $101.82 \pm 42.78$ & $53.26 \pm 46.10$ & 0.24 & 0.79 \\
\hline \multirow{3}{*}{$\begin{array}{l}\text { Volume of bone } \\
\text { graft }\left(\mathrm{cm}^{3}\right)\end{array}$} & $3 \mathrm{~m}$ & $1.44 \pm 0.26$ & $1.93 \pm 0.23$ & 1.72 & $0.031 *$ \\
\hline & $6 \mathrm{~m}$ & $1.02 \pm 0.37$ & $1.55 \pm 0.73$ & 0.42 & $0.001 * *$ \\
\hline & Resorption rate & $29.2 \%$ & $19.7 \%$ & 0.54 & $0.001 * *$ \\
\hline
\end{tabular}

* Statistical significance when $p \leq 0.05$

\section{DISCUSSION}

Closure of alveolar cleft is an important stage in treatment of patients with cleft lip and palate. This practice may have some potential benefits, such as closure of oronasal fistula,facilitating orthodontic treatment, and tooth replacement in cleft area $^{(4,5)}$.

There are several causes for ABG failure but the main cause of failure in ABG is contamination of graft after exposition in the nasal cavity. Therefore, some surgeons have advocated delayed ABG should until stable soft-tissue coverage has been achieved $^{(1,3)}$.

Several authors ${ }^{(5,11,23)}$ have been proposing the use of growth factors, and bone morphogenic proteins to enhance the results in $\mathrm{ABG}$, especially for clinical conditions requiring rapid healing in
$* *$ High statistically significant when $p \leq 0.01$

both soft and hard tissue. These authors had used a mix of growth factors or bone morphogenic proteins with cancellous bone to improve osteogenic capacity of graft

In the same context several researchers reported that HyA was capable to accelerate the onset of new bone formation when it is added to alloplastic bone graft for bone augmentation of alveolar defects. Where, HyA increases osteoblastic bone formation through increased mesenchymal cell differentiation and migration and decrease bone graft contamination $^{(24-26)}$.

Regards to use a PRF membrane in management of oronasal fistula in alveolar cleft patients, Dias et al ${ }^{(10)}$ had investigated PRF as an autogenous membrane to cover bone graft at palatal and labial 
aspects. They had concluded that PRF membrane supports exposure to the oral cavity without contamination and can stimulate healing of soft and bony tissue, acting as a physical barrier. However, this study had several drawbacks such as it did not determine number of cases, did not include cases with recurrent anterior palatal fistula .Therefore, our study was a atrial to benefit from advantages of PRF application as double layers with HyA in closure of recurrent oronasal fistula after previously failed ABG.

Clinical as well as radiological results after 6 months revealed stable hard and soft tissue conditions without recurrent oronasal fistula or bone graft loss in study groups except one case in group I ( $8.3 \%)$. Regarding post-operative infection, it was noticeable in group I than group II . This may be due to bacteriostatic effect of HyA which applied in group II. This matched with Pirnazar et al (17) study conclusion that stated at clinical application of HyA gels may reduce the bacterial contamination of surgical wound site, thereby, lessening the risk of post-surgical infection and promoting more predictable bone generation.

The present study used Osteon II collagen which is a newly developed alloplastic material containing $70 \%$ HA and 30\%b- TCP which are quite close to major mineral components of the human bone ${ }^{(27)}$. Moreover, bovine type I collagen was added to Osteon II material to increase its osteoconductivity .Where, the collagen is absorbed slowly over several weeks after helping the initial shaping (28) This matched with Bae JH et al. ${ }^{(29)}$ who found that the advantage of combining an insoluble HA with a resorbable $\beta$-TCP is that the slow-resorbing HA will maintain the volume, while faster-resorbing $\beta$-TCP will promote bone regeneration.

Regards to radiographic results, there was no significant difference between groups in terms of the mean thickness and mean height of the graft at all intervals. This can be explained by using the same alloplastic bone graft in both groups. In our study bone density values and bone graft volume showed statistically significant difference between both groups at 3 month interval and highly statistically significant difference at 6 month interval. where there was superiority for group II. Explanation of this,presence HyA in mixture of bone graft in group II lead to accelerate bone formation . This is in accordance with Bansal et al ${ }^{(30)}$ who reported that HyA has osteoconductive potential, and accelerates the bone regeneration by means of chemotaxis, proliferation and successive differentiation of mesenchyme cells.

Also, radiographic results of our study matched with Aslan et al. ${ }^{(31)}$ who demonstrated that the Osteon II collagen with hyaluronic acid groups has superiority bone healing histologically. On the other hand, Eric Aguado et al. ${ }^{(25)}$ investigated the use of HyA as an aqueous binder of the $\beta$ - TCP bone graft granules. On contrary to our results, they found out that the amount of formed bone was not significantly higher than with $\beta$ - TCP granules alone.

Finally,the positive results obtained in association with group II in all of the observation periods suggest a superior effect of PRF sandwiching technique combined with HyA gel application in alveolar bone grafting to prevent recurrent oronasal fistula.

\section{CONCLUSION}

As the findings of the present study indicted, the use of double layers of PRF gel in combination with mixing of HyA gel with alloplastic bone graft can improve results of $\mathrm{ABG}$, promoting faster healing and protection of bone graft in case of dehiscence, and decrease bone graft resorption rate. This method is an innovative alternative technique that can offer significant benefits for patients with a history of failed alveolar cleft grafting.

Funding: None.

Conflicts of interest: There are no conflict of interest 


\section{REFERENCES}

1. Craven C, Cole P, Hollier L Jr., Stal S. Ensuring success in alveolar bone grafting: A three-dimensional approach. J Craniofac Surg 2007;18:855-9.

2. Gupta C, Mehrotra D, Mohammad S, Khanna V, Singh GK, Singh G, et al. Alveolar bone graft with Platelet Rich Plasma in cleft alveolus. J Oral Biol Craniofac Res. 2013;3(1):3-8

3. Coots BK. Alveolar bone grafting: Past, present, and new horizons. Semin Plast Surg 2012;26:178-83.

4. Miloro M, Ghali GE, Larsen P, Waite P. Peterson's principals of oral and maxillofacial surgery. $3^{\text {rd }}$ ed. PMPHUSA, Ltd; 2011: 965-77.

5. Oyama T, Nishimoto S, Tsugawa T, Shimizu F. Efficacy of platelet-rich plasma in alveolar bone grafting. J Oral Maxillofac Surg. 2004;62(5):555-8.

6. Parwaz MA, Sharma RK, Parashar A, Nanda V, Biswas G, Makkar S. Width of clef palate and postoperative palatal fstula - Do they correlate? J Plast Reconstr Aesthet Surg 2009;62:1559-63.

7. Ahmed MK, Maganzini AL, Marantz PR, Rousso JJ. Risk of persistent palatal fistula in patients with cleft palate. JAMA Facial Plast Surg. 2015; 17:126-30.

8. Eberlinc A, Kozelj V. Incidence of residual oronasal fistulas: a 20-year experience. Cleft Palate Craniofac J. 2012; 49:643-8.

9. Lithovius RH, Ylikontiola LP, Sandor GK. Incidence of palatal fistula formation after primary palatoplasty in northern Finland. Oral Surg Oral Med Oral Pathol Oral Radiol. 2014; 118:632-6.

10. de Barros Dias BS, SchneiderT, Ladvocat Cintra HP. Platelet-rich fibrin in the Alveolar Bone graft in cleft lip and palate patient. Int J Growth Factors Stem Cells Dent 2018; 1:27-31.

11. González-Sánchez JG, Jiménez-Barragán K. Closure of recurrent cleft palate fistulas with plasma rich in growth factors. Acta Otorrinolaringol Esp 2011; 62:448-53.

12. Marukawa E, Oshina H, Ino G, Morita K, Omura K. Reduction of bone resorption by the application of platelet-rich plasma (PRP) in bone grafting of the alveolar cleft. J Craniomaxillofac Surg 2011; 39:278-83.

13. Preeja C, Arun S. Platelet-rich fibrin: Its role in periodontal regeneration. Saudi J Dent Res. 2014; 5(2):117-22.

14. Naik B, Karunakar P, Jayadev M, Marshal VR. Role of Platelet rich fibrin in wound healing: A critical review. J Conserv Dent. 2013;16(4):284-9.
15. Dimitriou R, Mataliotakis G, Maria G, Giannoudis C. The role of barrier membranes for guided bone regeneration and restoration of large bone defects: current experimental and clinical evidence. BMC Medicine 2012;10:81- 6

16. Roy S, Driggs J, Ehgharably H, Biswas S, Findley M, Khanna S, et al. Platelet rich fibrin matrix improves wound angiogenesis via inducing endothelial cell proliferation. Wound Repair Regen. 2011; 19:753-66.

17. Pirnazar P., Wolinsky L., Nachnani S., Haake S., Pilloni A.\& Bernard GW. Bacteriostatic effects of hyaluronic acid. J periodontal. 1999; 70(4):370-4.

18. Kim JJ, Song HY, Ben Amara H, Kyung-Rim K, Koo KT. Hyaluronic Acid Improves Bone Formation in Extraction Sockets with Chronic Pathology: A Pilot Study in Dogs. J Periodontol. 2016; 87(7): 790-5.

19. Choukroun J, Dohan DM, Diss A, Dohan SL, Dohan AJ, Mouhyi J, Gogly B .Platelet-rich fibrin (PRF): a secondgeneration platelet concentrate. Part II: platelet-related biologic features. Oral Surg Oral Med Oral Pathol Oral Radiol Endod 2006; 101:45-50.

20. S.R. Cohen, J. Kalinowski, D. LaRossa, P. Randall. Cleft palate fistulas: a multivariate statistical analysis of prevalence, etiology and surgical management. Plast Reconstr Surg, 87 (1991), pp. 1041-7.

21. Zhang W, Shen G, Wang X, Yu H, Fan L. Evaluation of alveolar bone grafting using limited cone beam computed tomography. Oral Surg Oral Med Oral Pathol Oral Radiol. 2012;113:542-8.

22. Zhou WN, Xu YB, Jiang HB, Wan L, Du YF. Accurate Evaluation of Cone-Beam Computed Tomography to Volumetrically Assess Bone Grafting in Alveolar Cleft Patients. J Craniofac Surg.2015;26:535-9.

23. Nadon F, Chaput B, Périssé J, de Bérail A, Lauwers F, Lopez R, et al. Interest of mineralized plasmatic matrix in secondary autogenous bone graft for the treatment of alveolar clefts. J Craniofac Surg 2015;26:2148-51.

24. Shamma1 MM, Ayad SS, El-dibany RM, Nagui DA. evaluation of the effect of hyaluronic acid mixed with biphasic calcium phosphate on bone healing around dental implants (experimental study). ADJ 2017;:42:104-11.

25. Aguado E, Florence P, Christine G, Eric G, Daniel C. $\beta$ TCP granules mixed with reticulated hyaluronic acid induces an increase in bone apposition. Biomed Mater. 2013; 9(1): 015001. 
26. Bansal J., Kedige SD.\& Anand S. Hyaluronic acid: a promising mediator for periodontal regeneration. Indian J Dent Res. 2010; 21(4):575-8.

27. Keating J.F \& McQueen M.M. Substitutes for autologous bone graft in orthopedic trauma. J Bone Joint Surg Br. 2001;83(1):3-8.

28. Lee EU, Kim DJ, Lim HC, Lee JS, Jung UW, Choi SH. Comparative evaluation of biphasic calcium phosphate and biphasic calcium phosphate collagen composite on osteoconductive potency in rabbit calvarial defect. Biomaterials Research. 2015; 19: 1-7.
29. Bae JH, Kim YK, Kim SG, Yun PY, Kim JS. Sinus bone graft using new alloplastic bone graft material (Osteon)-II: clinical evaluation. Oral Surg Oral Med Oral Radiol Endod 2010; 109:14-20.

30. Bansal J., Kedige SD.\& Anand S. Hyaluronic acid: a promising mediator for periodontal regeneration. Indian J Dent Res. 2010; 21(4):575-8.

31. Aslan M.,Simsek G. \& Dayi E. The effect of hyaluronic acid-supplemented bone graft in bone healing: experimental study in rabbits. J Biomater Appl. 2006; 20(3):209-20. 


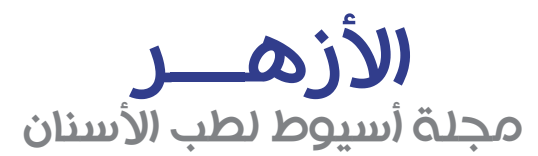

النشر الرسمي لكلية طب الأسنان جامعة الأزهر أسيوط الكاية

\title{
فاعلية تقنية ساندويتش الفيبرين الغنس بالصفائح الدموية

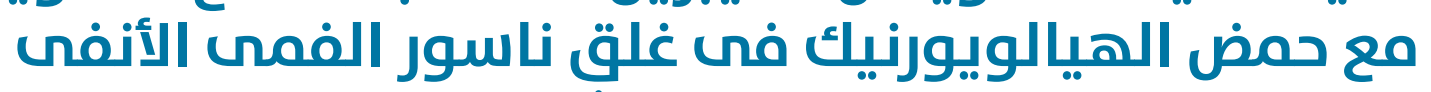

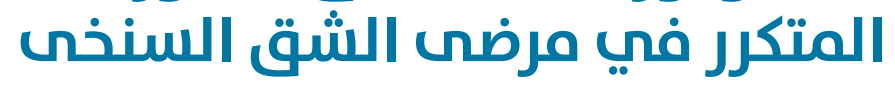

\author{
عبدالعزيز بيومي عبد الله بيومي ** محمد محجوب محمد العشماوي \\ 1. قسـم جراحة الفهم والوجه والفكين، كلية طب الاسنان، ( أسيوطربنين)، جامعة الازهر، مصر

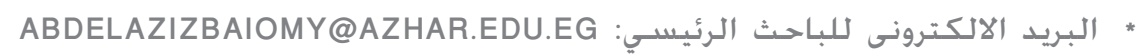

(الملخص : (1) n

الهدف: كان الهدف من ذلك هو تقييم فعالية تقنية السـاندويتش بالفيبرين الغنى بالصفائح الدموية المرتبطة بحمض الهيالورونيك الممزوج الهماج

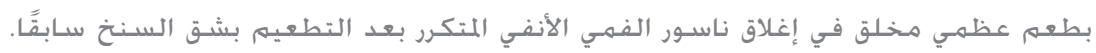

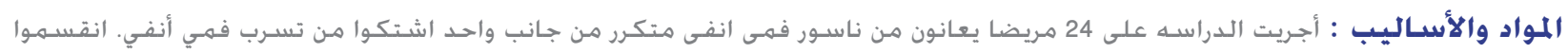

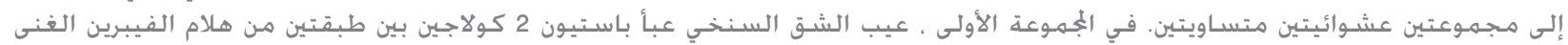

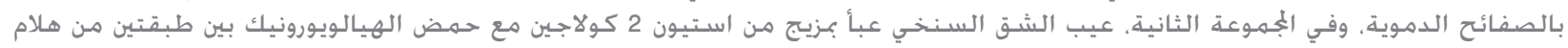

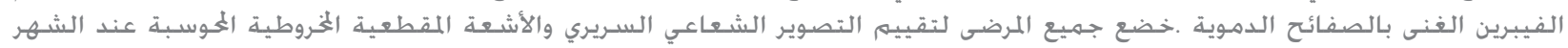
الثالث و السـادس بعد الجراحة.

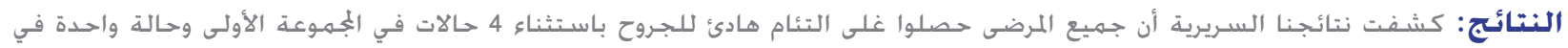

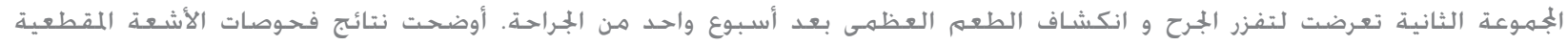

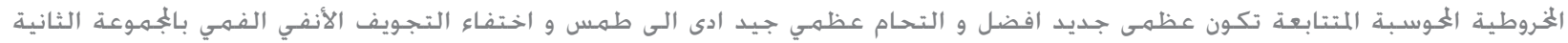

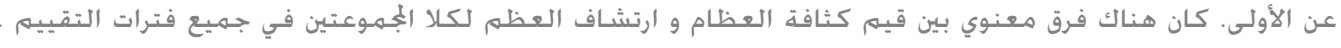

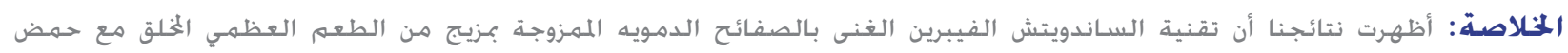

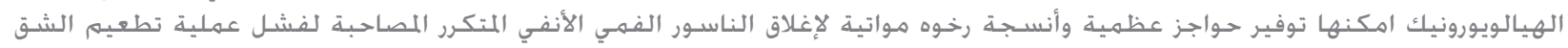
السـنخي السـابقة.

الكعلمـات المفتاحية : الفيبرين الغنى بالصفائح الدموية, حمض الهيالويورنيك, الشق السنخى, ناسـور الفمى الأنفى, ترقيع العظم

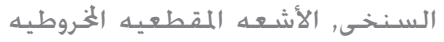

